\title{
Determination of theobromine and caffeine in some Malaysian beverages by liquid chromatography-time-of- flight mass spectrometry
}

\author{
Fouad F Al-Qaim ${ }^{1,2 *}$, Ali Yuzir ${ }^{1}$, Zainab H Mussa ${ }^{1,3}$ \\ ${ }^{1}$ Malaysia-Japan International Institute of Technology (MJIIT) Universiti Teknologi Malaysia, Jalan Sultan Yahya Petra, 54100 \\ Kuala Lumpur, Malaysia, ${ }^{2}$ Department of Chemistry, Faculty of Sciences for Women, University of Babylon, Iraq, ${ }^{3}$ School of \\ Chemical Sciences and Food Technology, Faculty of Science and Technology, National University of Malaysia (UKM), 43600 \\ Bangi, Selangor, Malaysia
}

*For correspondence: Email: fouadalkaim@yahoo.com; Tel: +60-17-3394821

\begin{abstract}
Purpose: To determine the concentration of theobromine (TB) and caffeine (CF) in tea and other beverages using liquid chromatography-time of flight-mass spectrometry (LC-TOF-MS).

Methods: The extract of caffeine and theobromine from tea and other beverages was filtered by 0.45 $\mu m$ nylon micro-syringe and then injected into a LC-ToF-MS system. Theobromine and caffeine were separated using Thermo Scientific C18-column (length $250 \mathrm{~mm}$, width $2.1 \mathrm{~mm}$ and diameter $5 \mu \mathrm{m}$ ). Acetonitrile-methanol ( $\mathrm{ACN}-\mathrm{MeOH}, 3: 1 \mathrm{v} / \mathrm{V})$ was used as mobile phase $B$, while mobile phase $A$ was $0.1 \%$ FA in DIW. The volume injected was $30 \mu \mathrm{L}$ at a rate of $0.3 \mathrm{~mL} / \mathrm{min}$.

Results: Good linearity was obtained in the range of $0.3-400$ and $0.2-200 \mathrm{mg} / \mathrm{L}$ for theobromine and caffeine, respectively (regression coefficient $\left(R^{2}\right)>0.970$ ). The limits of detection were 0.15 and 0.05 $\mu \mathrm{g} / \mathrm{mL}$ for theobromine and caffeine, respectively. The highest concentrations of caffeine and theobromine determined in tea samples were 159.1 and $255.8 \mathrm{mg} / \mathrm{L}$, respectively.

Conclusion: Theobromine and caffeine have been successfully analysed in tea, coffee and soft drinks. LC-TOF-MS is an accurate and promising instrument for the determination of the studied compounds in beverages.
\end{abstract}

Keywords: Theobromine, Caffeine, Tea, Coffee, LC-TOF/MS

\begin{abstract}
This is an Open Access article that uses a funding model which does not charge readers or their institutions for access and distributed under the terms of the Creative Commons Attribution License (http://creativecommons.org/licenses/by/4.0) and the Budapest Open Access Initiative (http://www.budapestopenaccessinitiative.org/read), which permit unrestricted use, distribution, and reproduction in any medium, provided the original work is properly credited.

Tropical Journal of Pharmaceutical Research is indexed by Science Citation Index (SciSearch), Scopus, International Pharmaceutical Abstract, Chemical Abstracts, Embase, Index Copernicus, EBSCO, African Index Medicus, JournalSeek, Journal Citation Reports/Science Edition, Directory of Open Access Journals (DOAJ), African Journal Online, Bioline International, Open-J-Gate and Pharmacy Abstracts
\end{abstract}

\section{INTRODUCTION}

Methylxanthines, theobromine and caffeine are used as analgesics, diet aids, and cold/flu remedies in numerous popular carbonated drinks. They are also the main compounds found in tea, coffee, sodas, chocolate, and various energy drinks. More than 120,000 tons of caffeine is consumed worldwide annually $[1,2]$. Malaysia-Regular Beverage Consumption revealed that coffee and tea are the most consumed drinks by Malaysian people [3].

The present study is focused on the analysis of 
TB and CF in coffee and tea; given that both drinks are preferred in restaurants, coffee shops, households, and markets. To the best of our knowledge, this study is the first to evaluate the contents of compounds in coffee and tea in Malaysia. The analysis of theobromine and caffeine in foods, biological fluids, environmental samples, plants, and water, was provided with different instrumental methods, such as highperformance liquid chromatography (HPLC) [4], gas chromatography-mass spectrometry-flame ionization detection (GC-MS-FID) [5], Fourier transform-infrared spectrophotometry (FT-IR) [6], near-infrared spectroscopy [7], UV-Vis spectrophotometry [8], FT-Raman spectrometry [9], and capillary electrophoresis (CE) [10]. Of these techniques, HPLC which offers advantages, such as simplicity and selectivity coupled with a UV-Vis detector, was deemed the preferred analysis system for the analysis of theobromine and caffeine $[8,11,12]$. However, the co-elution of compounds is a common phenomenon when a UV-vis detector is used with HPLC [13]. This limitation, and other challenges, can be resolved by coupling with a highly specific, sensitive, and accurate ToF-MS analyser that is considered a suitable and confirmative technology to measure trace levels of TB and CF.

ToF-MS is a highly accurate and specific detector. With this detector, data is given as a four-decimal-point $\mathrm{m} / \mathrm{z}$ that responds, almost exclusively, to electrospray ionization as an ionization source [14]. The separation and extraction of TB and CF from tea, coffee, soft drinks, and other beverages has been reported in several previous studies with different extraction methods $[15,16]$.

The aim of this study is to develop a simple and accurate LC-ToF-MS method, using an extremely limited reagent for the analysis of theobromine and caffeine in beverages. Direct injection, without any further sample preparation, was provided using LC-ToF-MS which is an accurate technique to extract caffeine and theobromine from the total ion chromatogram using a $20 \mathrm{mD}$ mass window.

\section{EXPERIMENTAL}

\section{Chemicals}

Pure standards ( $\geq 99 \%$ ) of CF and TB, CAS no. 58-08-2 and CAS no. 83-67-0, respectively, were purchased from Sigma-Aldrich (USA). HPLCgrade organic solvents (acetonitrile $(\mathrm{ACN})$ and methanol $(\mathrm{MeOH})$ ) were purchased from Merck (Germany). Formic acid as additive was obtained from Merck (Germany). Deionized water was collected from the Faculty of Sciences and Technology, UKM, Malaysia.

\section{Standard solution preparation}

Stock solutions $1 \mathrm{mg} / \mathrm{mL}$ for theobromine and caffeine were prepared by dissolving in $\mathrm{MeOH}$, $0.01 \mathrm{~g}$ of compound was dissolved in $10 \mathrm{~mL}$ of $\mathrm{MeOH}$, and stored at $20{ }^{\circ} \mathrm{C}$ for further preparation. Further solutions were prepared by diluting the stock solution $(1 \mathrm{mg} / \mathrm{L})$ with deionized water. All solutions were injected in triplicate and analysed using LC-ToF-MS. Calibration curves were built by plotting peak area against concentration.

\section{Sample collection and preparation}

All the samples were collected from different local markets in Malaysia and are as presented in Table 1.

Tea samples were extracted in hot water. A $1.0 \mathrm{~g}$ sample of tea was placed in $50 \mathrm{~mL}$ of distilled water at $95-100{ }^{\circ} \mathrm{C}$ for $5 \mathrm{~min}$ as per normal preparation for a daily consumer. Tea extracts were filtered through a $0.45 \mu \mathrm{m}$ Nylon microsyringe filter. A $5 \mathrm{~mL}$ sample of coffee was filtered and then injected directly into the LC-MS. Dissolved gases were excluded from beverages using an ultrasonic water bath for $10 \mathrm{~min}$, prior to sample analysis. Thereafter, the samples were filtered using a $0.45 \mu \mathrm{m}$ Nylon micro-syringe filter to obtain a transparent sample ready for analysis.

\section{LC-ToF-MS instrumentation and conditions}

Separation of theobromine and caffeine was performed using a liquid chromatography instrument (Dionex Ultimate 3000/LC 09115047 (USA)) equipped with a vacuum degasser, a quaternary pump, and an auto-sampler. Sample aliquots of $30 \mu \mathrm{L}$ were injected into $5 \mu \mathrm{m}, 2.1 \mathrm{~mm}$ $\times 250 \mathrm{~mm}$ Thermo Scientific C18 column. Electrospray ionisation (ESI) was utilized as an ionization source.

TB and CF were analysed in positive ion ( $\mathrm{PI}$ ) mode. The elution of compounds was achieved with $\mathrm{ACN}-\mathrm{MeOH}(3: 1, \mathrm{v} / \mathrm{v})$ as mobile phase $B$ and $0.1 \%$ FA in DIW as mobile phase $A$ at 0.3 $\mathrm{mL} / \mathrm{min}$.

The gradient elution was as follows: $5 \%$ B $(0$ $\min ) \rightarrow 60 \%$ B (linear increased in 3 min) $\rightarrow 97$ $\%$ B (linear increased in $3 \mathrm{~min}$ ) $\rightarrow 97 \%$ B (hold 5 $\min ) \rightarrow 5 \%$ B (linear decreased in $0.1 \mathrm{~min}) \rightarrow 5$ $\% \mathrm{~B}$ (hold $5 \mathrm{~min}$ ). 
Table 1: Tea and beverages samples description

\begin{tabular}{|c|c|c|c|}
\hline $\begin{array}{l}\text { Name } \\
\text { brand }\end{array}$ & $\begin{array}{l}\text { Name } \\
\text { manufacturer }\end{array}$ & $\begin{array}{c}\text { Batch } \\
\text { no. }\end{array}$ & $\begin{array}{c}\text { Expire } \\
\text { date }\end{array}$ \\
\hline $\begin{array}{l}\text { Al-Kbous } \\
\text { tea }\end{array}$ & $\begin{array}{l}\text { Al-Kbous } \\
\text { Industrial } \\
\text { Trading and } \\
\text { Investment Co. } \\
\text { W.L.L. Amman, } \\
\text { Jordan. }\end{array}$ & $\begin{array}{c}6- \\
251361- \\
100104\end{array}$ & $12 / 10 / 2019$ \\
\hline Lipton tea & $\begin{array}{l}\text { PT Unilever } \\
\text { Indonesia Tbk } \\
\text { Kawasan } \\
\text { Industri, Bekasi, } \\
\text { Indonesia. }\end{array}$ & $\begin{array}{c}8- \\
888086- \\
021001\end{array}$ & $13 / 12 / 2019$ \\
\hline $\mathrm{BOH}$ tea & $\begin{array}{l}\text { BOH Plantations } \\
\text { Sdn. Bhd. Kuala } \\
\text { Lumpur, } \\
\text { Malaysia. }\end{array}$ & $\begin{array}{c}9- \\
556015- \\
010080\end{array}$ & $30 / 11 / 2019$ \\
\hline $\begin{array}{l}\text { Sari- } \\
\text { Wangi } \\
\text { tea }\end{array}$ & $\begin{array}{l}\text { Sari Wangi Teh } \\
\text { Asli, Indonesia. }\end{array}$ & $\begin{array}{c}8- \\
999999- \\
195649\end{array}$ & $24 / 06 / 2018$ \\
\hline $\begin{array}{l}\text { Al-Wazah } \\
\text { tea }\end{array}$ & $\begin{array}{l}\text { Finlays Colombo } \\
\text { Ltd. Welisara, } \\
\text { Sri Lanka. }\end{array}$ & $\begin{array}{c}4- \\
791002- \\
019454\end{array}$ & $30 / 10 / 2019$ \\
\hline $\begin{array}{l}\mathrm{BOH} \\
\text { green tea }\end{array}$ & $\begin{array}{l}\text { BOH Plantations } \\
\text { Sdn. Bhd. Kuala } \\
\text { Lumpur, } \\
\text { Malaysia. }\end{array}$ & $\begin{array}{c}9- \\
556015- \\
010226\end{array}$ & $\begin{array}{c}08 / 01 / \\
2020\end{array}$ \\
\hline $\begin{array}{l}\text { The Cap } \\
\text { Masjid }\end{array}$ & $\begin{array}{l}\text { TEH Wangi Ros. } \\
\text { Sdn. Bhd. Kuala } \\
\text { Lumpur, } \\
\text { Malaysia. }\end{array}$ & $\begin{array}{c}9- \\
555195- \\
100000\end{array}$ & $31 / 12 / 2010$ \\
\hline $\begin{array}{l}\text { Ahmad } \\
\text { tea }\end{array}$ & $\begin{array}{l}\text { Ahmad Tea Ltd. } \\
\text { Hampshire, } \\
\text { England. }\end{array}$ & $\begin{array}{c}0- \\
54881- \\
00616-3\end{array}$ & $16 / 01 / 2010$ \\
\hline $\begin{array}{l}\text { Mahmood } \\
\text { tea }\end{array}$ & $\begin{array}{l}\text { Mahmood Tea } \\
\text { Int. (PVT) Ltd. } \\
\text { Colombo-02, Sri } \\
\text { Lanka. }\end{array}$ & $\begin{array}{c}4- \\
796000- \\
550725\end{array}$ & $30 / 11 / 2019$ \\
\hline $\begin{array}{l}\text { White } \\
\text { coffee }\end{array}$ & $\begin{array}{l}\text { ETIKA Sdn. } \\
\text { Bhd. Selangor, } \\
\text { Malaysia. }\end{array}$ & $\begin{array}{c}9- \\
556404- \\
116423\end{array}$ & $30 / 11 / 2019$ \\
\hline Nescafe & $\begin{array}{l}\text { Nestle products } \\
\text { Sdn. Bhd. } \\
\text { Selangor, } \\
\text { Malaysia. }\end{array}$ & $\begin{array}{c}9- \\
556001- \\
054005\end{array}$ & $30 / 11 / 2018$ \\
\hline Milo & $\begin{array}{l}\text { Nestle products } \\
\text { Sdn. Bhd. } \\
\text { Selangor, } \\
\text { Malaysia. }\end{array}$ & $\begin{array}{c}9- \\
556001- \\
081322\end{array}$ & $19 / 06 / 2018$ \\
\hline Red Bull & $\begin{array}{l}\text { T.C. } \\
\text { Pharmaceuticals } \\
\text { Industries Co., } \\
\text { Ltd. Prachin } \\
\text { Buri, Thailand. }\end{array}$ & $\begin{array}{c}\text { 8- } \\
888307- \\
882572\end{array}$ & $07 / 05 / 2019$ \\
\hline $\begin{array}{l}\text { Lipton } \\
\text { iced tea }\end{array}$ & $\begin{array}{l}\text { ETIKA Sdn. } \\
\text { Bhd. Selangor, } \\
\text { Malaysia. }\end{array}$ & $\begin{array}{c}9- \\
556404- \\
049035\end{array}$ & $15 / 11 / 2018$ \\
\hline Pepsi & $\begin{array}{l}\text { ETIKA Sdn. } \\
\text { Bhd. Selangor, } \\
\text { Malaysia. }\end{array}$ & $\begin{array}{c}9- \\
556404- \\
001033 \\
\end{array}$ & $\begin{array}{l}18-10- \\
2018\end{array}$ \\
\hline
\end{tabular}

Theobromine was separated at $5.43 \mathrm{~min}$, whereas caffeine was separated at $6.51 \mathrm{~min}$. The
LC-ToF-MS (Bruker, Germany) was operated in single reaction mode, using the positive electrospray ionization (ESI+) mode. The source conditions were as follows: drying gas temperature, $190{ }^{\circ} \mathrm{C}$, drying gas flow rate, 8.0 $\mathrm{L} / \mathrm{min}$, set endplate offset, - $500 \mathrm{~V}$, set collision cell RF, 250 Vpp, MS capillary voltages, 4000 (PI), set capillary, $4000 \mathrm{~V}$, and nebulizer pressure, 4.0 bar. A mixture of sodium hydroxide and formic acid was used as the lock mass at $m / z 90.9766-974.8132$.

\section{Quantification and confirmation method}

TB and CF were identified and quantified using LC-ToF-MS instrument based on exact retention times and accurate mass value $(\mathrm{m} / \mathrm{z})$ of the protonated molecular ions $[\mathrm{M}+\mathrm{H}]^{+}$. Theobromine and caffeine were extracted at 0.02 Da. Theobromine and caffeine were identified based on two factors; the accurate mass value $(\mathrm{m} / \mathrm{z})$ and the retention time of the molecular ion $[\mathrm{M}+\mathrm{H}]^{+}$.

\section{Evaluation of selectivity}

Selectivity was evaluated by comparing the chromatograms of three different samples; real sample, spiked real sample, and deionized water. The results revealed that no interfering peaks were present at the TB and CF retention times.

\section{Determination of linearity and sensitivity}

The linearity ranged between 0.3 and $400 \mathrm{mg} / \mathrm{L}$ for theobromine and 0.2 and $200 \mathrm{mg} / \mathrm{L}$ for caffeine.

Calibration curves were generated for each compound by plotting the peak area against the concentration of each compound using the linear regression model. For the analytical chromatography instruments, LOQ was the lowest concentration corresponding to $\mathrm{S} / \mathrm{N}$ ratio $\geq$ 10.

\section{Determination of precision and accuracy}

Precision and accuracy of the LC-ToF-MS method were evaluated at three different concentrations (1, 50, and $200 \mu \mathrm{g} / \mathrm{mL})$ and $(5,25$ and $100 \mu \mathrm{g} / \mathrm{mL}$ ) for theobromine and caffeine, respectively. Inter-day precision was evaluated by performing three replicates of three different concentrations. Intra-day precision was assessed within three consecutive days. The precision was presented in terms of relative standard deviation percentage (RSD \%). The accuracy was expressed as the ratio of mean observed 
concentration to nominal concentration, as a percentage.

\section{Statistical analysis}

Each assay was repeated at least three times. Means were analysed statistically by analysis of variance (ANOVA) followed by Duncan's test, using SPSS software, Version 19. The results were considered significantly different at $p<$ 0.05 .

\section{RESULTS}

The linearity of the LC-ToF-MS method of theobromine and caffeine was assessed by analysing seven concentrations $(0.3,1.0,10.0$, $50.0,100.0,200.0$, and $400.0 \mathrm{mg} / \mathrm{L})$ and $(0.2$, $1.0,5.0,25.0,50.0,100.0$, and $200.0 \mathrm{mg} / \mathrm{L})$ for theobromine and caffeine, respectively. Calibration curves were obtained by the plotting peak area of theobromine and caffeine separately against a working standard concentration. Calibration curves were fitted to least-square linear regression. The results showed good linearity for caffeine and theobromine; in which $\left(R^{2}\right)$ was 0.979 and 0.999 , respectively.

The precision of the LC-ToF-MS method was assessed by analysis of three samples replicates within the same day (inter-day) and for three different days (intra-day) (see Table 2). The precision was determined by analysing three different concentrations for theobromine (1, 50 and $200 \mu \mathrm{g} / \mathrm{mL}$ ) and caffeine $(5,25$ and 100 $\mu \mathrm{g} / \mathrm{mL})$, respectively, on three different days. The results were in accordance with standard method validation [17]. RSD \% values ranged from 3.11 to $13.22 \%$ for intra-day precision and 2.52 to $11.43 \%$ for inter-day precision. Accuracy was determined by adding known amounts of TB and CF as a mixture to the solvent $(1,50$, and 200 $\mu \mathrm{g} / \mathrm{mL})$ and $(5,25$, and $100 \mu \mathrm{g} / \mathrm{mL})$, respectively. The accuracy results were good, ranging from 99 to $108 \%$ for intra-day and 94 to $110 \%$ for interday (as shown in Table 2).

Figure 1 shows that no peaks interfered at the retention times of TB (5.43 min) and CF (6.51 min). Chromatogram $A$ refers to the standard solution of a mixture of TB and CF. The tea sample was spiked with the mixture of these two compounds and then injected into LC-ToF/MS as shown in chromatogram $\mathbf{B}$.
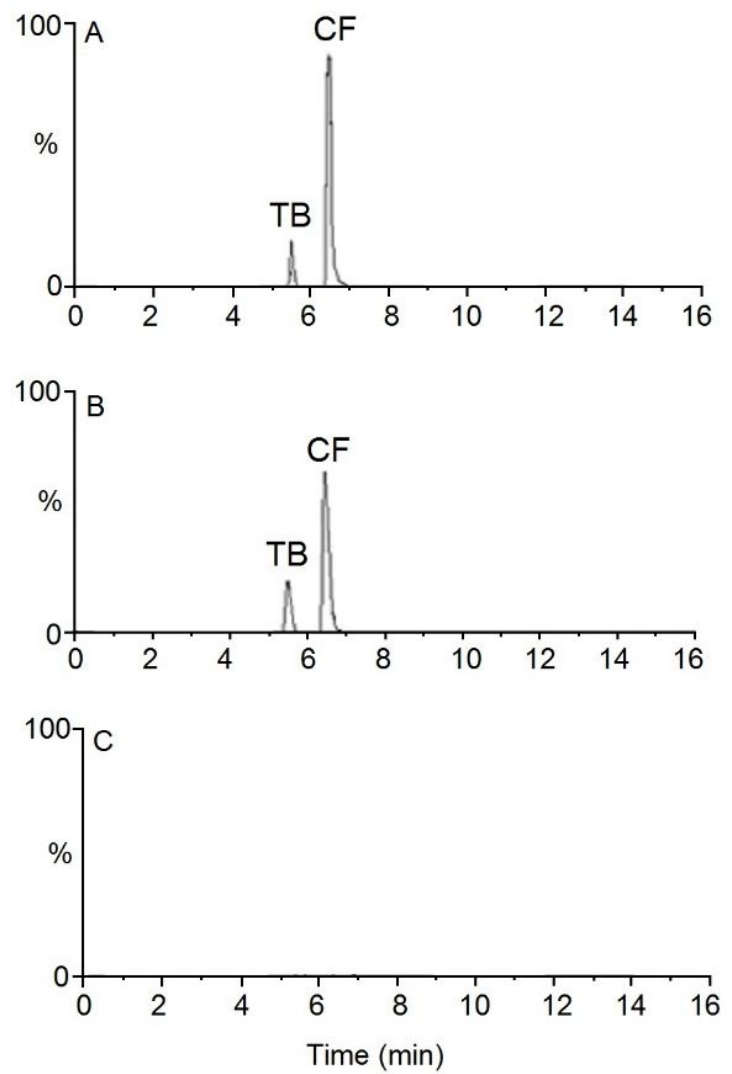

Figure 1: Representative chromatograms of caffeine and theobromine as a mixture: $(\mathrm{A})$ standard mixture of caffeine and theobromine $(50 \mu \mathrm{g} / \mathrm{mL})$, (B) tea sample spiked with caffeine and theobromine $(50 \mu \mathrm{g} / \mathrm{mL})$, and (C) blank solvent

Table 2: Intra-day and inter-day precision and accuracy data for the analysis of caffeine and theobromine in real samples

\begin{tabular}{llcccc}
\hline Compound & $\begin{array}{l}\text { Nominal } \\
\text { concentration } \\
\text { (mg/L) }\end{array}$ & \multicolumn{2}{c}{ Intra-day (n=4) } & \multicolumn{2}{c}{ Inter-day (n=6) } \\
\cline { 2 - 6 } & & Precision (RSD \%) & $\begin{array}{c}\text { Accuracy } \\
(\mathbf{\%})\end{array}$ & $\begin{array}{c}\text { Precision (RSD } \\
\text { \%) }\end{array}$ & $\begin{array}{c}\text { Accuracy } \\
(\%)\end{array}$ \\
\hline Caffeine & 5.0 & 11.37 & 106 & 10.11 & 94 \\
& 25.0 & 8.31 & 99 & 6.49 & 104 \\
Theobromine & 100.0 & 3.11 & 102 & 2.55 & 98 \\
& 1.0 & 13.22 & 99 & 11.43 & 98 \\
& 50.0 & 5.11 & 102 & 4.95 & 94 \\
\hline
\end{tabular}


No peaks appeared TB and CF in deionized water (blank solvent); this method was therefore selective for TB and CF; as shown in chromatogram C.

Environmental samples are commonly too polluted with organic and inorganic contaminants and are therefore called complex matrices. To prevent the alteration or interference of other compounds to the target compounds, a narrow window was used in the ToF-MS analyser to reconstruct the chromatographic traces; consequently the selectivity of the instrument was increased. Extracted ion chromatograms (EICs) from the total ion chromatogram (TIC) were provided at $0.02 \mathrm{Da}$ for theobromine and caffeine (as shown in Figure 2).

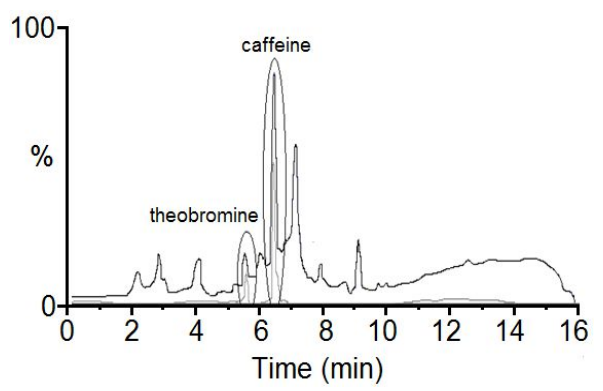

Figure 2: Extracted ion chromatogram (gray color) for $\mathrm{TB}$ and $\mathrm{CF}$ from the total ion chromatogram (black color) using LC-ToF/MS at $20 \mathrm{mD}$

Caffeine and theobromine were analysed in $\mathrm{PI}$ mode; therefore the resulting products are protonated molecular ions $[\mathrm{M}+\mathrm{H}]^{+}$. The product ion spectra and fragmentation patterns for CF and TB are shown in Figure 3.
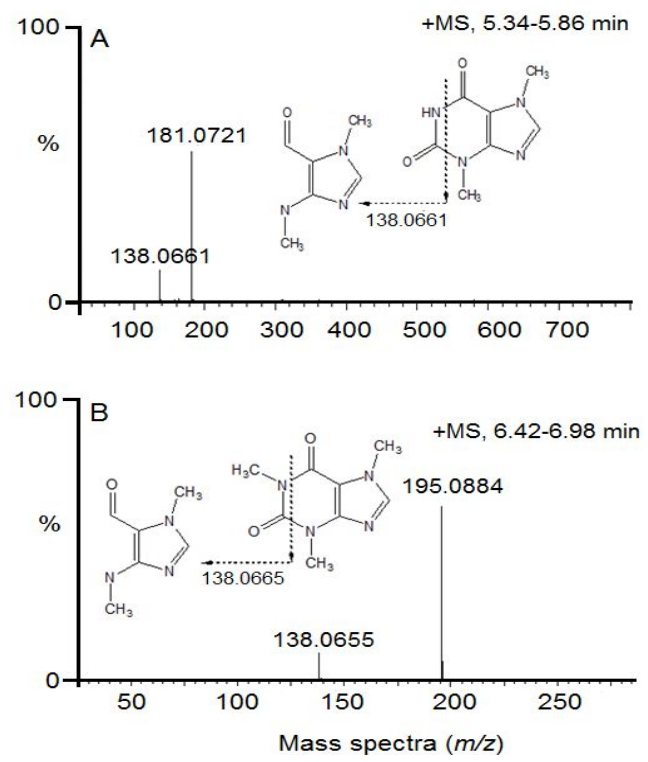

Figure 3: Mass spectra of theobromine A and caffeine B
All 15 samples were analysed using LC-ToF-MS. Retention times were 5.43 and $6.51 \mathrm{~min}$ for TB and CF, respectively (as shown in Figure 2). The concentrations of theobromine and caffeine in samples are presented in Table 3.

Table 3: Caffeine and theobromine concentration $(\mathrm{mg} / \mathrm{L})$ in real samples

\begin{tabular}{|c|c|c|c|}
\hline $\begin{array}{l}\mathbf{N} \\
\mathbf{0}\end{array}$ & Sample & Caffeine & Theobromine \\
\hline & & Mean \pm SD & Mean \pm SD \\
\hline 1 & Tea Al-Kbous & $143.4 \pm 2.7$ & $186 \pm 6.61$ \\
\hline 2 & Lipton tea & $133.9 \pm 1.8$ & $110.6 \pm 5.2$ \\
\hline 3 & BOH Tea & $138.3 \pm 4.5$ & $126.7 \pm 5.0$ \\
\hline 4 & $\begin{array}{l}\text { Sari wangi } \\
\text { tea }\end{array}$ & $140.6 \pm 0.6$ & $110.2 \pm 3.7$ \\
\hline 5 & Al-Wazah tea & $159.1 \pm 1.5$ & $255.8 \pm 12.4$ \\
\hline 6 & $\begin{array}{l}\mathrm{BOH} \text { green } \\
\text { Tea }\end{array}$ & $107.7 \pm 2.7$ & $102.3 \pm 5.9$ \\
\hline 7 & $\begin{array}{l}\text { Teh cap } \\
\text { masjid }\end{array}$ & $133.4 \pm 2.7$ & $119.8 \pm 1.8$ \\
\hline 8 & Ahmad tea & $125.3 \pm 2.1$ & $140.3 \pm 3.9$ \\
\hline 9 & Mahmoud tea & $117.5 \pm 3.2$ & $104.2 \pm 10.7$ \\
\hline $\begin{array}{l}1 \\
0\end{array}$ & $\begin{array}{l}\text { White coffee } \\
\text { beverage }\end{array}$ & $82.7 \pm 2.9$ & $<L O Q$ \\
\hline $\begin{array}{l}1 \\
1\end{array}$ & $\begin{array}{l}\text { Nescafe } \\
\text { original } \\
\text { beverage }\end{array}$ & $83.1 \pm 2.6$ & $16.2 \pm 0.7$ \\
\hline $\begin{array}{l}1 \\
2\end{array}$ & $\begin{array}{l}\text { Milo } \\
\text { beverage }\end{array}$ & $30.4 \pm 2.5$ & $222.2 \pm 5.3$ \\
\hline $\begin{array}{l}1 \\
3\end{array}$ & $\begin{array}{l}\text { Red bull } \\
\text { beverage }\end{array}$ & $136.1 \pm 1.7$ & $\mathrm{Nd}^{*}$ \\
\hline $\begin{array}{l}1 \\
4\end{array}$ & $\begin{array}{l}\text { Lipton ice tea } \\
\text { beverage }\end{array}$ & $67.2 \pm 5.1$ & $20.4 \pm 3.4$ \\
\hline $\begin{array}{l}1 \\
5\end{array}$ & $\begin{array}{l}\text { Pepsi } \\
\text { beverage }\end{array}$ & $102.7 \pm 1.7$ & $\mathrm{Nd}^{*}$ \\
\hline
\end{tabular}

\section{DISCUSSION}

The investigation of the LC-ToF-MS method's selectivity was discussed after the comparison of the peak chromatograms; which resulted in standard solutions, tea sample spiked with standards and deionized water without standards. The regression coefficients were 0.999 and 0.979 for TB and CF, respectively. It was observed that limit of quantification (LOQ) values of 0.15 and $0.05 \mu \mathrm{g} / \mathrm{mL}$ for theobromine and caffeine, respectively, were more acceptable than in previous studies $[18,19]$.

The precision and accuracy of the LC-ToF-MS method was assessed for theobromine and caffeine. Three replicates were performed for three different concentrations and then all samples were injected into the LC-ToF-MS instrument. The results showed that RSD \% was 
$\leq 13.22$; which is acceptable in this range of concentration.

It is well-known that analysis of complex matrices is a challenge; because the signals of target compounds could be impacted by organic and inorganic components that are both present in the real sample, together with analytes. The selectivity of the LC-ToF-MS method was enhanced by selecting a narrow window (0.02 Da) for analysis of theobromine and caffeine in actual samples. Improvement of $\mathrm{S} / \mathrm{N}$ ratio, from twofold to fourfold, was observed after reducing the daltonic value from 0.5 to $0.02 \mathrm{Da}$ [20]. The mass value $(\mathrm{m} / \mathrm{z})$ for the protonated molecular ions $[\mathrm{M}+\mathrm{H}]^{+}$was used for quantitation analysis. The errors obtained for mass values were between 0.6 and $1.2 \mathrm{ppm}$.

All data related to accurate mass were calculated using Bruker Daltonics Data Analysis software; which provided the experimental and theoretical mass value $(\mathrm{m} / \mathrm{z})$ and elemental composition for molecular ions $[\mathrm{M}+\mathrm{H}]^{+}$. From the results, the mass errors were less than 0.5 ppm for both CF and TB; which are more acceptable than in previous study [21].

The most intense peaks observed, at $\mathrm{m} / \mathrm{z}$ 195.0884 for $\mathrm{CF}$ and 181.0721 for TB, represented protonated molecular ion $[\mathrm{M}+\mathrm{H}]^{+}$. A small daughter peak appeared at $\mathrm{m} / \mathrm{z} 138.066$ after the fragmentation of CF and TB. This small, intense peak refers to the loss of $\mathrm{C}_{2} \mathrm{H}_{3} \mathrm{NO}$ from CF and $\mathrm{CNHO}$ from TB to form $\mathrm{C}_{6} \mathrm{H}_{7} \mathrm{~N}_{3} \mathrm{O}$; as reported previously by Choi et al. They investigated the formation of metabolite of $\mathrm{m} / \mathrm{z}$ 138.12 from theobromine and caffeine after losing $\mathrm{C}_{2} \mathrm{H}_{3} \mathrm{NO}$ and $\mathrm{CNHO}$ moieties, respectively [22].

The highest concentration of caffeine was present in $\mathrm{Al}-\mathrm{Kbous}$ tea, with the concentration reaching $143 \mathrm{mg} / \mathrm{L}$. Meanwhile, in Pepsi, the caffeine concentration was $103 \mathrm{mg} / \mathrm{L}$; which is almost identical to that of original Cane from the market. For beverages, caffeine was highly detected in Red Bull at $136.1 \mathrm{mg} / \mathrm{L}$. The mean caffeine content of carbonated soft drinks was lower than that of energy drinks. This finding is in line with the same result reported by Fatima et al [1]. However, the mean concentration of CF in 9 tea samples was $133 \mathrm{mg} / \mathrm{L}$. The highest concentrations of TB were detected in Al-Wazah tea and Milo at 256 and $222 \mathrm{mg} / \mathrm{L}$, respectively. All of these beverages are a major source of contamination of the water samples by theobromine and caffeine; as shown in previous studies [23,24].

\section{CONCLUSION}

The findings of the present study indicate that LC-ToF-MS method is accurate and sensitive enough to detect theobromine and caffeine in tea and other beverages. This study is the first to report on the analysis of theobromine and caffeine in Malaysian tea and beverages. Thus, ToF-MS is a powerful analyser that can be used to confirm the presence of theobromine and caffeine in tea and other beverages.

\section{DECLARATIONS}

\section{Acknowledgement}

The authors thank the staff of Central Research of Instrumentation Management (CRIM) for providing the LC-TOF/MS facilities used in this study as well as ALIR staff for providing ultrapure water. This work was financially supported by MJIIT-UTM.

\section{Conflict of interest}

No conflict of interest is associated with this work

\section{Contribution of the authors}

The authors declare that this work was done by the authors named in this article and all liabilities pertaining to claims relating to the content of this article will be borne by them.

\section{REFERENCES}

1. Mazdeh FZ, Moradi Z, Moghaddam G, MoradiKhatoonabadi Z, Aftabdari FE, Badaei P, Hajimahmoodi M. Determination of synthetic food colors, caffeine, sodium benzoate and potassium sorbate in sports drinks. Trop J Pharm Res 2016; 15: 183-188.

2. Zou J, Li N. Simple and environmental friendly procedure for the gas chromatographic-mass spectrometric determination of caffeine. J Chromatogr A 2006; 1136 : 106-110.

3. Malaysia - regular beverage consumption, 2016 [cited 2017 October 20]. Available from https://www.statista.com/statistics/561175/malaysiaregular-beverage-consumption/

4. Ali HS, Abdullah AA, Pınar PT, Yardım Y, Şentürk Z. Simultaneous voltammetric determination of vanillin and caffeine in food products using an anodically pretreated boron-doped diamond electrode: Its comparison with HPLC-DAD. Talanta 2017; 170: 384-391.

5. Rahim AA, Saad B, Osman $H$, Hashim N, Yahya S, Talib KM. Simultaneous determination of diethylene glycol, diethylene glycol monoethyl ether, coumarin and 
caffeine in food items by gas chromatography. Food Chem 2011; 126: 1412-1416.

6. Palo M, Kogermann K, Genina N, Fors D, Peltonen J, Heinämäki J, Sandler N. Quantification of caffeine and loperamide in printed formulations by infrared spectroscopy. J Drug Deliv Sci Tec 2016; 34: 60-70.

7. Zhang $X$, Li W, Yin B, Chen W, Kelly DP, Wang X, Zheng $K, D u Y$. Improvement of near infrared spectroscopic (NIRS) analysis of caffeine in roasted Arabica coffee by variable selection method of stability competitive adaptive reweighted sampling (SCARS). Spectrochim Acta A 2013; 114: 350-356.

8. Shehata $A B$, Rizk MS, Rend EA. Certification of caffeine reference material purity by ultraviolet/visible spectrophotometry and high-performance liquid chromatography with diode-array detection as two independent analytical methods. J Food Drug Anal 2016; 24: 703-715.

9. Armenta S, Garrigues S, de la Guardia M. Solid-phase FT-Raman determination of caffeine in energy drinks. Anal Chim Acta 2005; 547: 197-203.

10. Meinhart AD, Bizzotto CS, Ballus CA, Prado MA, Bruns RE, Filho JT, Godoy HT. Optimisation of a CE method for caffeine analysis in decaffeinated coffee. Food Chem 2010; 120: 1155-1161.

11. Jeon DB, Hong YS, Lee GH, Park YM, Lee CM, Nho EY, Kim KS. Determination of volatile organic compounds, catechins, caffeine and theanine in Jukro tea at three growth stages by chromatographic and spectrometric methods. Food Chem 2017; 219: 443-452.

12. Al-Qaim FF, Jusof SH, Abdullah MP, Mussa ZH, Tahrim NA, Khalik WM, Othman MR. Determination of caffeine in surface water using solid phase extraction and high performance liquid chromatography. Malays J Anal Sci 2017; 21: 95-104.

13. Ptolemy AS, Tzioumis E, Thomke A, Rifai S, Kellogg M. Quantification of theobromine and caffeine in saliva, plasma and urine via liquid chromatography-tandem mass spectrometry: A single analytical protocol applicable to cocoa intervention studies. J Chromatogr $B$ 2010; 878: 409-416.

14. Zielinski AAF, Haminiuk CWI, Beta T. Multi-response optimization of phenolic antioxidants from white tea (Camellia sinensis L. Kuntze) and their identification by LC-DAD-Q-TOF-MS/MS. LWT-Food Sci Technol 2016; 65: 897-907.
15. Aresta A, Palmisano F, Zambonin CG. Simultaneous determination of caffeine, theobromine, theophylline, paraxanthine and nicotine in human milk by liquid chromatography with diode array UV detection. Food Chem 2005; 93: 177-181.

16. Jodynis-Liebert J, Flieger J, Matuszewska A, Juszczyk J. Serum metabolite/caffeine ratios as a test for liver function. J Clin Pharmacol 2004; 44: 338-347.

17. International Conference on Harmonization, ICH, US FDA Federal Register 1997; 62: 27463.

18. Tzanavaras PD, Themelis DG. Development and validation of a high throughput high-performance liquid chromatographic assay for the determination of caffeine in food samples using a monolithic column. Anal Chim Acta 2007; 581: 89-94.

19. Jafari MT, Rezaei B, Javaheri M. A new method based on electrospray ionisation ion mobility spectrometry (ESI-IMS) for simultaneous determination of caffeine and theophylline. Food Chem 2011; 126: 1964-1970.

20. Al-Qaim FF, Abdullah MP, Othman MR, Latip J, Afiq W. A validation method development for simultaneous $L C$ ESI-TOF/MS analysis of some pharmaceuticals in Tangkas river-Malaysia. J Braz Chem Soc 2014; 25 : 271-281.

21. Petrovic M, Gros M, Barcelo D. Multi-residue analysis of pharmaceuticals in wastewater by ultra-performance liquid chromatography-quadrupole-time-of-flight mass spectrometry. J Chromatogr A 2006; 1124: 68-81.

22. Choi EJ, Bae SH, Park JB, Kwon MJ, Jang SM, Zheng YF, Lee YS, Lee SJ, Bae SK. Simultaneous quantification of caffeine and its three primary metabolites in rat plasma by liquid chromatographytandem mass spectrometry. Food Chem 2013; 141: 2735-2742.

23. Al-Qaim FF, Abdullah MP, Othman MR, Mussa ZH, Zakaria Z, Latip J, Afiq WM. Investigation of the environmental transport of human pharmaceuticals to surface water: A case study of persistence of pharmaceuticals in effluent of sewage treatment plants and hospitals in Malaysia. J Braz Chem Soc 2015; 26 : 1124-1135.

24. Al-Qaim FF, Abdullah P, Othman MR, Latip J, Afiq WM. Development of analytical method for detection of some pharmaceuticals in surface water. Trop $\mathrm{J}$ Pharm Res 2013; 12: 609-616. 